\title{
Non-Formal Environmental Education and NGO-School Link for Environmental Awareness and Protection
}

\author{
Dr. Kabita Choudhury
}

Associate Professor, Dept. of Education, Kamrup College, Chamata (Assam)

\begin{abstract}
The protection and improvement of human environment is a major issue which affects the wellbeing of people and economic development throughout the world. In this rapidly changing man-made environment the need of restoring the originality of natural environment becomes a deep concern for the whole mankind. Lack of awareness, proper knowledge among the common people regarding the conservation of environment and its resources can lead to different socio-ecological and environmental problems. Unless the environmental education is reached to the grass root level and cover all sections of people no efforts on environmental protection can be expected. Therefore environmental education is designed as a lifelong process covering all sections of people and it is expected that environmental education will provide a fundamental understanding of bio-physica1 environmental problems confronting man, how these problems can be solved with sound knowledge and attitude. The life-long environmental education is known as the non-formal environmental education and it is designed for any age group, participating in social, economic, cultural development of the community. The present study tries to discuss the importance of NGOs and its linkage with the secondary schools in environmental awareness and protection as the NOn-governmental Organizations constitute an integral part of non-formal environmental education.
\end{abstract}

Keywords: Non-formal environmental education, NGOs, NGO-School Linkage

\section{Article Publication}

㬂 Published Online: 15-Dec-2021

*Author's Correspondence

8 Dr. Kabita Choudhury

9 Associate Professor, Dept. of Education, Kamrup College, Chamata (Assam)

$\triangle$ kchoudhury_2010@rediffmail.com

C 2021The Authors. Published by RESEARCH REVIEW International Journal of Multidisciplinary. This is an open access article under the CC BY-

NC-ND license

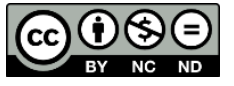

(https://creativecommons.org/licenses/ by-nc-nd/4.0/)

\section{Introduction}

Non-formal environmental education as defined by the International Consultation Meeting on Developing Nonformal Environmental Education (1987), is the type of intentional education for the development of, among various sectors of the community, environmental concepts, skills, attitudes and ethics which are carried on in different communities which may or may not include schools and universities.

The history of non-formal environmental education is much older than that of the formal system of education. Non-formal environmental education was much valued in India. Three religions- Hinduism, Buddhism and Jainism, which have roots in India, advocated strongly for the need to protect the elements of environment. In the modern history the need of non-formal environmental education got worldwide importance since the early part of eighty.

The International Workshop at Belgrade (1975) came out with the historic document called 'The Belgrade Charter' stressing the importance of non-formal environmental education and to strengthen it the following needs were highlighted there:

i. International exchange of information on all aspects of out-of-school environmental education,

ii. Reinforcement of educational and community support,

iii. A direction for non-formal environmental education programme at the national and local levels.

iv. Extensive research related to environmental education of young learners with special emphasis on early childhood awareness,

v. Research into the use of non-school learning environment for environmental education, 
vi. Research on the strategic role of information.

The International Consultation Meeting on Developing Non-formal environmental education was held at Ain Shams University in 1987. This was the first international meet on non-formal environmental education and it defined the meaning, aims and objectives, strategies and guidelines of non-formal environmental education.

Regarding the goals, objectives and guiding principles of non-formal environmental education the Consultation Meet of 1987 recommended that both formal and non-formal environmental education must have common goals, objectives and principles. Depending upon the nature and abilities of the target group, effective programmes of the non-formal environmental education may be developed. Formal education system in the society must come closer to the non-formal education.

The target groups of non-formal environmental education are 'the youth and adults, individually and collectively, from all sections of the population such as the family, workers, managers and decision-makers in environmental as well as non-environmental fields.' In some cases the target population is somewhat homogeneous: workers in a certain industry, farmers, club members, policemen etc.

The planning, organization and methodology of non-formal environmental education varies enormously from one country to another. In Nepal, Radio Nepal broadcasts a regular weekly programme on ecology with an emphasis on the preservation of forests, a particular problem in Nepal. The Iraqi Environmental Protection Society has confined its activities to the production of publications aimed at stimulating public awareness. The Nature Protection League of Poland, in co-operation with various youth and adult groups, has set up school nature camps and environmental research centers for young naturalists. In Indonesia the government accepted that a nonformal environmental education programme was needed to enhance public awareness of environmental problems. In Wales, Prince of Wales Committee, a charitable organization, is responsible for the supervision of a large number of environmental improvement projects, often using the labour of the young unemployed. In India too, in addition to many organizations efforts at non-formal level, the Ministry of Environment and Forest accords priority to the promotion of non-formal environmental education and creation of awareness among all sections of the society through diverse activities using traditional and modern media of communication. For this purpose a programme known as National Environment Awareness Campaign (NEAC) is being started since 1986 and different awareness programmes are carried out among the masses on various environmental issues.

A variety of contents or parts are included in non-formal environmental education based on the nature, importance and priorities of environmental problems and the background of the target groups. The major contents of non-formal environmental education can be outlined as follows:

1. Adult Education

2. Rural Youth and Non-student Youth

3. Children Activities

4. Eco-development Camps

5. Non-governmental Organizations (NGOs)

6. Public Representatives

7. Training Senior Executives Administrators

8. Foundation Courses

9. Research and Development Programme

10. Centers of Excellence

11. Development of Trained manpower

12. Development of educational material and teaching aids

13. World Environment Day

14. National Environment Awareness Campaign (NEAC) 
The UNESCO-UNEP International Environmental Education Programme (1986) had also outlined that the augmentation of different kinds of non-formal environmental education programmes with those that are more structural educative and interact, is most important for those countries in which environmental issues are immediate and relevant to the day-to-day lives of the people. In such countries the formal education system is often disadvantaged by lack of resources, high drop-out rates and insufficient placements at secondary school and subsequently the non-formal environmental education programmes assume an increased significance.

\section{Objectives of the Study}

1) To study the opinions of the NGO -heads in regard to NGO-school Link for promoting environmental awareness and protection.

2) To study the opinions of the headmasters of the secondary schools in regard to NGO-school link for promoting environmental awareness and protection.

3) To find out the programmes / activities done jointly by the NGOs and Schools on environmental awareness and protection.

\section{Sample}

For carrying out the present study fifteen environmental NGOs and fifteen secondary schools were selected from the Kamrup district of Assam on the basis of purposive sampling method. At the time of selection, the sample necessary study was done whether the NGOs and the secondary schools have done some environmental programmes together.

\section{Tools}

Two self -constructed oppinionnaire were applied among the heads (Director,president of the NGOs and headmasters of the secondary schools)of both the NGOs and Schools.

\section{Result and Discussion:}

\section{Opinion of NGO Heads in Ngo-School Link:}

The responses of the fifteen heads of the selected NGOs towards the link between the NGOs and secondary schools are shown in the following table.

Table -1: Opinion of NGO Heads on NGO-School Link.

$\mathrm{N}=15$

\begin{tabular}{|c|c|c|c|}
\hline $\begin{array}{c}\text { Sl } \\
\text { No. }\end{array}$ & Statements & Yes (f) & $\%$ \\
\hline 1. & $\begin{array}{l}\text { Consider secondary School as an effective associate for developing } \\
\text { environmental awareness in the society. }\end{array}$ & 15 & $100 \%$ \\
\hline 2. & $\begin{array}{l}\text { NGOs target Programme can easily be transmitted to the mass people } \\
\text { through the collaboration of schools. }\end{array}$ & 12 & $80 \%$ \\
\hline 3 & $\begin{array}{l}\text { Interest for protection of local environment by the joint efforts of school } \\
\text { and NGO. }\end{array}$ & 15 & $100 \%$ \\
\hline 4 & $\begin{array}{l}\text { Joint activities of NGOs and Schools bring positive effects on the } \\
\text { society. }\end{array}$ & 15 & $100 \%$ \\
\hline 5 & $\begin{array}{l}\text { Secondary Schools teacher involvement is important for the successful } \\
\text { Programmes. }\end{array}$ & 12 & $80 \%$ \\
\hline 6. & $\begin{array}{l}\text { Observation of World Environment Day and other related days in } \\
\text { association with schools become more meaningful. }\end{array}$ & 14 & $93.3 \% \%$ \\
\hline 7 & $\begin{array}{l}\text { Assistance in formation of Eco-club and NGC in schools by the NGOs } \\
\text { is an important task. }\end{array}$ & 14 & $93.3 \%$ \\
\hline 8 & $\begin{array}{l}\text { Schools should be provided printed materials or others on environmental } \\
\text { issues by the NGOs. }\end{array}$ & 9 & $60 \%$ \\
\hline 9 & $\begin{array}{l}\text { Show interest to do project on environmental protection involving the } \\
\text { schools. }\end{array}$ & 14 & $93.3 \%$ \\
\hline
\end{tabular}




\begin{tabular}{|l|l|l|l|}
\hline 10 & $\begin{array}{l}\text { NGO-School link will be an effective drive-in environmental awareness } \\
\text { and protection movement. }\end{array}$ & 15 & $100 \%$ \\
\hline
\end{tabular}

Table 5.35 reveals that all the $(\mathrm{n}=15) \mathrm{NGO}$ heads consider secondary school as an effective associate for developing environmental awareness in the society. $80 \%$ of NGO head opine that NGOs target programme can easily be transmitted to the mass people through the collaboration of schools and all $(100 \%)$ heads are in favour of protecting the local environment by the joint efforts of school and NGO and all the NGO heads (100\%) highly respond towards the positive effects of NGO-Schools joint activities. $80 \%$ of heads give positive response for the secondary schools teachers involvement in programmes. On the other hand $93.3 \%$ of NGO head think that observation of world Environment Day and other related days in association with schools become more meaningful. It is also found from the above table that $93.3 \%$ head opines for the assistance in formation of Ecoclub and NGC in schools by the NGOs and for providing printed materials and others on environmental issues respectively. $93.3 \%$ of $\mathrm{NGO}$ heads are found to be interested in doing project on environmental protection involving the schools and all the NGO heads $(100 \%)$ think that NGO-School link will be an effective drive in environmental awareness and protection movement.

\section{Opinion of school heads in NGO-School link:}

The responses of the fifteen heads of selected schools on the link between the secondary schools and NGOs are shown through the following table.

Table -2: Opinion of School Heads on NGO-School Link $\quad \mathrm{N}=15$

\begin{tabular}{|c|c|c|c|}
\hline S1 No. & Statement & Yes & $\%$ \\
\hline 1 & $\begin{array}{l}\text { Consider environmental NGOs an effective associate for developing environmental } \\
\text { awareness in the society. }\end{array}$ & 13 & $86.60 \%$ \\
\hline 2 & $\begin{array}{l}\text { Environmental programmers of the school can reach outside people through the } \\
\text { collaboration of NGOs. }\end{array}$ & 13 & $86.60 \%$ \\
\hline 3 & Interest for protection of local environment by the joint efforts of the school and NGO. & 12 & $80 \%$ \\
\hline 4 & Joint activities of school and NGOs bring positive effects on the society. & 13 & $86.60 \%$ \\
\hline 5 & Allow teachers to participate in training programs arranged by the NGOs. & 11 & $73.30 \%$ \\
\hline 6 & $\begin{array}{l}\text { Observation of world environment day and other relared days in association with NGOs } \\
\text { become more meaningful. }\end{array}$ & 15 & $100 \%$ \\
\hline 7 & Assistance from the NGOs in formation of eco club and NGC in school is necessary. & 10 & $66 \%$ \\
\hline 8 & $\begin{array}{l}\text { Schools should be provided printed materials or others environmental issues by the } \\
\text { environmental NGOs. }\end{array}$ & 15 & $100 \%$ \\
\hline 9 & Show intrest to do project on environmental protection with the NGOs. & 12 & $80 \%$ \\
\hline 10 & $\begin{array}{l}\text { NGO- School link will be an effective drive in the environmental awareness and protection } \\
\text { movement. }\end{array}$ & 15 & $100 \%$ \\
\hline
\end{tabular}

Table-5.36 reveals that $86.6 \%$ of School head considers environmental NGOs as an effective associate of school for developing environmental awareness in the society. They $(86.6 \%)$ also opine that the environmental programmes of the school can reach outside people through the collaboration of NGOs. On the other hand $80 \%$ school heads is found to be in favour of protection of local environment by the joint efforts of school and NGO. Regarding the positive effects of joint activities on the society, $86.6 \%$ heads show positive response and $73.3 \%$ heads is found in favour of allowing the teachers for participation in training programmes arranged by the NGOs. All the NGOs (100\%) are in favour of meaningfulness of joint observation of World Environment Day and other related Days, providing printed materials on environmental issues from the NGOs and the future effectiveness of NGO-school link for environmental awareness and protection movement respectively. In regard to interest for doing environmental projects with the NGOs it is found that $80 \%$ School heads respond positively.

From table 5.35 and table 5.36 it can be said that both the NGO and School heads reveal a high and satisfactory opinion in regard to NGO-School link for environmental issues. 
A comparison of the opinions of both NGO and School heads on NGO-School Link is shown through the following table.

Table -3 Comparison of NGO Head and School Head Responses on NGO-School Link

\begin{tabular}{|c|c|c|c|c|c|}
\hline \multirow{2}{*}{$\begin{array}{l}\mathrm{Sl} \\
\mathrm{No}\end{array}$} & \multirow[t]{2}{*}{ Statement } & \multicolumn{2}{|l|}{$\operatorname{Yes}(\mathrm{F})$} & \multicolumn{2}{|c|}{ percentage } \\
\hline & & $\begin{array}{l}\text { NGO } \\
\text { Head }\end{array}$ & $\begin{array}{l}\text { Schoo } \\
1 \text { Head }\end{array}$ & $\begin{array}{l}\text { Ngo } \\
\text { Head }\end{array}$ & $\begin{array}{l}\text { School } \\
\text { Head }\end{array}$ \\
\hline 1. & $\begin{array}{l}\text { Consider environmental NGOs/ secondary schools an } \\
\text { effective associate for each other in developing } \\
\text { environmental awareness in the society. }\end{array}$ & 15 & 13 & $100 \%$ & $86.6 \%$ \\
\hline 2. & $\begin{array}{l}\text { Need of collaboration between NGOs and schools for } \\
\text { transmitting the respective environmental }\end{array}$ & 12 & 13 & $80 \%$ & $\begin{array}{l}86.6 \% \\
80 \%\end{array}$ \\
\hline 3. & $\begin{array}{l}\text { Interest for protection of local environment by the } \\
\text { joint effort of NGO and school. }\end{array}$ & 15 & 13 & $100 \%$ & $86.6 \%$ \\
\hline 4. & $\begin{array}{l}\text { Joint activities of school and NGO bring positive } \\
\text { effect on the society. }\end{array}$ & 12 & 11 & $80 \%$ & $73.3 \%$ \\
\hline 5. & $\begin{array}{l}\text { Need to teacher's participation in training } \\
\text { programmers arranged by the NGOs. }\end{array}$ & 14 & 15 & $93.3 \%$ & $100 \%$ \\
\hline 6 & $\begin{array}{l}\text { Observation of world Environment Day and other } \\
\text { related Days jointly become more meaningful. }\end{array}$ & 9 & 10 & $60 \%$ & $66.6 \%$ \\
\hline
\end{tabular}

The Mean, SD, SE $\delta$ of NGO heads and School heads and the correlation of opinion between them are computed and presented as follows -

Table-4

Mean, SD and SE $\delta$ of NGO Heads and School Heads opinion on NGO-School Link.

\begin{tabular}{|c|c|c|c|c|}
\hline Type of Respondent & $\mathrm{N}$ & $\mathrm{M}$ & $\mathrm{SD}$ & SE $\delta$ \\
\hline NGO Head & 15 & 8.60 & 1.5 & .38 \\
\hline School Head & 15 & 8.73 & .96 & .24 \\
\hline
\end{tabular}

Table-5.38 shows that there exists least Mean and $\delta$ difference (.13 and .54 respectively) between the NGO head and School heads' responses on NGO-school link in environmental issues.

The co-efficient of correlation of opinion between these two types of respondent was computed out by applying formula 28 (Garrett, 1981) and the value of ' $r$ ' was found as 0.73 which indicates that a high relationship exists in opinion between NGO heads and school heads on 'NGO-School Link' in environmental issues.

\section{Joint Programmes/Activities on Environmental Issues:}

Programmes or activities for the purpose of environmental awareness and protection were found to be carried out by the NGOs and secondary schools jointly. Such programmes or activities on environmental issues done by the surveyed NGOs and schools are presented through the following table.

Table--5 Joint Drive of NGO-School on Environmental Issues

\begin{tabular}{|c|l|l|l|}
\hline $\begin{array}{c}\text { Sl. } \\
\text { No. }\end{array}$ & Programmes / Activities & Purpose & $\%$ of total joint drive \\
\hline 1 & Procession & Awareness generation & $73.3 \%$ \\
\hline 2 & Cycle rally & Awareness \& conservation & $20 \%$ \\
\hline 3 & Nature's camp & Environmental education \& training & $40 \%$ \\
\hline 4 & Poster campaigning & Awareness generation & $46 \%$ \\
\hline 5 & Summer Eco-camp & Environmental education and training & $46.6 \%$ \\
\hline 6 & Workshop/seminar on environmental & Environmental protection & $53 \%$ \\
\hline
\end{tabular}




\begin{tabular}{|c|l|l|l|}
\hline & conservation & & \\
\hline 7 & Observation of World Environment Day & Awareness & $66.6 \%$ \\
\hline 8 & Plantation Programme & Awareness & $86.6 \%$ \\
\hline 9 & $\begin{array}{l}\text { Bird watching and Identification } \\
\text { Programme }\end{array}$ & Environmental conservation & $20 \%$ \\
\hline
\end{tabular}

From the above table it can be observed that the highest percentage $(86.6 \%)$ is found in the plantation activities done jointly by the NGOs and schools and $73.3 \%$ joint activities are done on procession for environmental awareness generation and workshop/seminar on environmental conservation are held by 53\% NGO-school joint activities. On the other hand it is also found that "Cycle Rally" and "Bird Watching and Identification" programmes are done only by $20 \%$ jointly. "Nature Camp" and "Poster Campaigning" are carried out by $40 \%$ and $46.6 \%$ respectively. $46 \%$ seminars eco-camp is found to be arranged jointly. It is also seen from the above table that $66.6 \%$ NGO-School link is associated with the observation of World Environment Day.

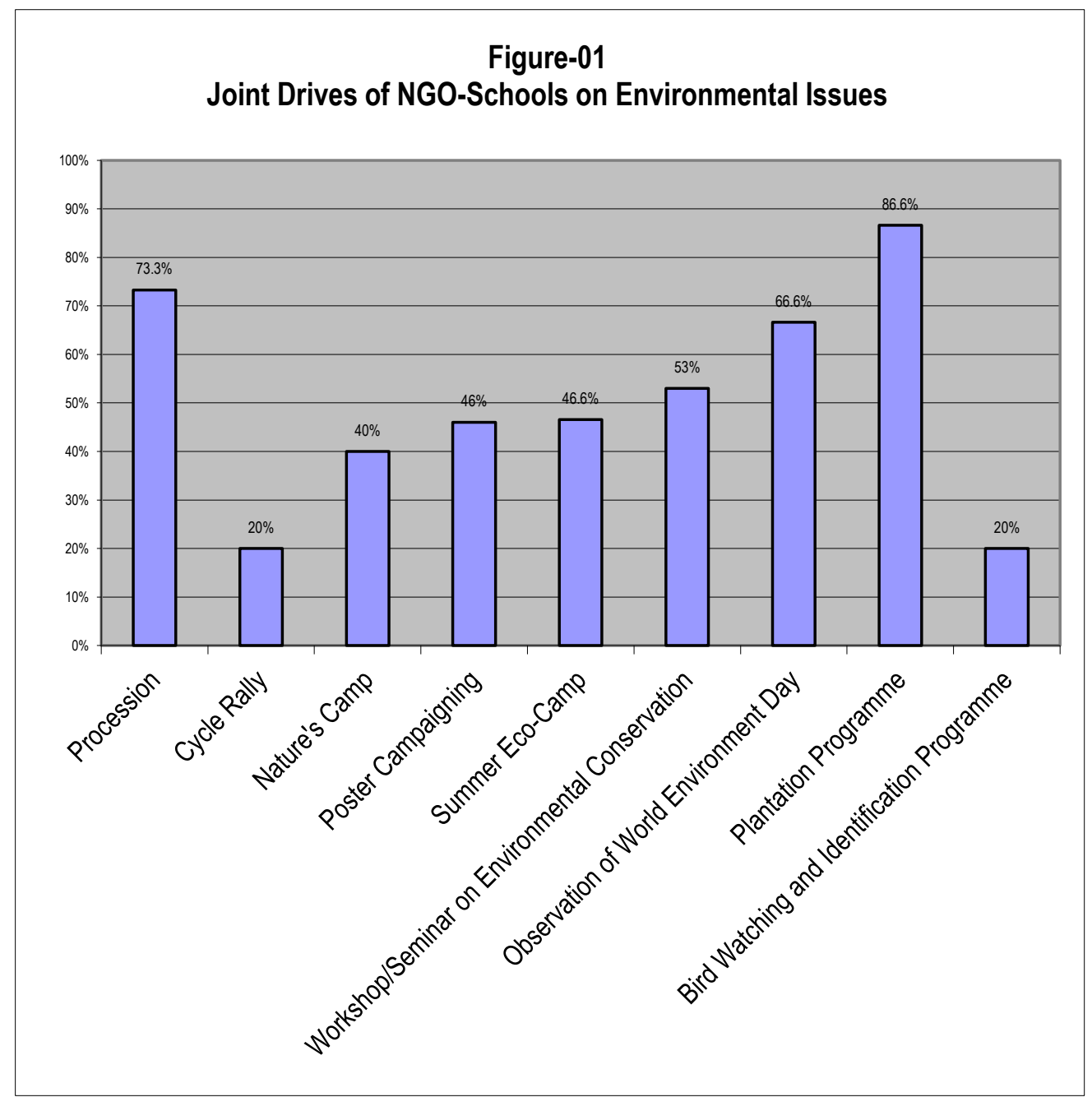

\section{Conclusion:}

The findings related to the NGO and school head's opinion and the joint drives carried out by NGO-School for enhancing environmental awareness and protections in the society are found to be satisfactory. Hence it can be said that the secondary schools and the environmental NGOs have developed a satisfactory link to promote environmental awareness and protection in the society.Such kind of linkage between the formal and non-formal environmental education bears much signifance at the present time of growing environmental crisis. 


\section{References:}

Agrawal,Anil and others :State of India's Environment, the Citizens fifth report,Vol-2,New Delhi,CSE,1999.

Ali,Sabri,Dr. Mazar: Environmental Education, environment and People,Vol-II,No-3,Hyderabad,2004.

Bandhu,d: Environmental Education:Indian Environmental Society,New Delhi,1981.

Choudhury,Dr.Kabita : "A Study of the Complementary role of formal and non-formal educational agencies in environmental awareness and protection"-Ph.D thesis submitted to Gauhati University,2009.

Rangarajan Mahesh (Edt.):Environmental Issues in India.

Sharma,R.A Environmental education ,Surya Publication Meerut 2004. 